\title{
Laos and Library Development
}

\begin{abstract}
Libraries are not yet viewed by the government of Laos as essential for national development, yet some emerging growth factors may be observed. There have been at least three recent proposals made for Lao library enhancement, but thus far necessary funding has not been forthcoming as a result. Most of the library service presently available in the nation is rendered by foreign agencies. This situation will have to change.
\end{abstract}

L $\triangle$ IBRARIES ARE NOT always a good thing. In developing countries, for example, libraries are often unorganized, unused, and poorly staffed and may easily be misinterpreted by the local government as a waste of time and not worthy of further thought or investment. For this reason libraries in developing nations sometimes cripple their own further development. The immediate bibliothecal future of such nations therefore often lies not in the establishment of large libraries (although these will ultimately be needed), but rather in the development of small, useful, well-run collections of books which will stimulate the desire of the populace to want more. When this occurs, the public will demand library development on their own terms for their own resources; i.e., libraries will develop.

In Laos today, a key factor for proper library development is lacking; i.e., the interest and support of the Royal Lao Government. There have been three library programs proposed in the past decade, but no one of them has as yet come to the active attention of the government.

The first, written in 1958 by Tay Keolouangkhot and Thao Kéne was called

Mr. Marcus is a library consultant with the Asia Foundation in Laos.
"National Library and Museum System in Laos." In it the authors pointed out the need for a national library, describing it in the following terms:

It will be a depository of essential cultural values, of original documents, of historical and geographical studies, and it will provide our national archive. The National Library will also serve as a centre of cultural life and scientific research. The lack of such an institution has handicapped serious scholarly research in Laos into artistic, historical and geographical, economic, and literary problems.

The establishment of a National Library for Laos will be a sign of its nationhood and a witness to its independence; and it will proclaim the respect of Laos for moral and intellectual values.

The second proposal, which is currently before UNESCO for approval, is George Chartrand's "UNESCO Report on Library Development in Laos." In addition to stating the need for a depository law, trained librarians, planning, funds, and new facilities, Mr. Chartrand proposed the establishment of a "Bureau des Bibliothèques du Laos" which would be expected to:

1. Publicize the importance of libraries and reading, particularly to school teachers.

2. Plan the organization of school libraries, taking into account the urgent 
needs of the less-favored areas of Laos.

3. Centralize book buying for all libraries.

4. Receive book gifts from various donors and distribute them intelligently.

5. Organize and centralize all technical services before distributing books.

6. Visit libraries and gather statistics for use in establishing long term developmental programs.

7. Build a librarian's library with primary emphasis on bibliographies for children and for other specialized groups of readers.

8. Establish a book binding department.

The third proposal, drafted by a member of the International Voluntary Services, calls for Royal Lao Government approval and sponsorship of a Library Development Team (LDT). The LDT would help organize libraries requesting assistance, create the materials necessary to run these libraries, and set standards for good library practice. Foreign advisors would work with Lao counterparts appointed and paid by the RLG. It is to be hoped that the example set by the LDT would help stimulate the desire to establish a permanent bureau of libraries in the RLG.

In order to evaluate these proposals, it is necessary to know something about the country of Laos and its libraries. If the statistics about Laos are compared with similar figures for Oregon, the meaning of a developing library system will be clear. Both Laos and Oregon have a population of about two million people widely distributed over more than ninety thousand square miles of land. Both have rich timber resources. Laos, however, cannot market its timber or other resources effectively because it is a landlocked country lacking roads,

TABLE 1. Holdings and Circulation of Libraries in Laos

\begin{tabular}{|c|c|c|c|c|c|c|c|}
\hline & 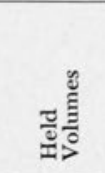 & 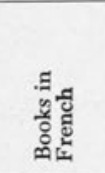 & 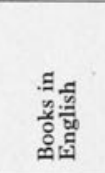 & 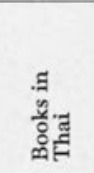 & 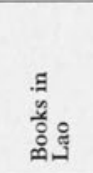 & 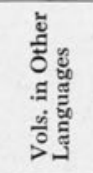 & 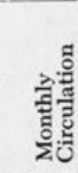 \\
\hline \multicolumn{8}{|l|}{ Lao Libraries: } \\
\hline Archives Nationale & 2,484 & & .. & & & & 5 \\
\hline National Library . . & 8,957 & $\begin{array}{r}8,857 \\
98\end{array}$ & & 100 & & & 72 \\
\hline $\begin{array}{l}\text { National Museum } \\
\text { Ecole de Médecine }\end{array}$ & $\begin{array}{r}2,805 \\
762\end{array}$ & $\begin{array}{r}98 \\
662\end{array}$ & 100 & & 698 & 1,815 & 30 \\
\hline \multicolumn{8}{|l|}{ Ecole Supérieure de } \\
\hline Pédagogie & 7,927 & 1,769 & 4,914 & 1,101 & 116 & 27 & 660 \\
\hline Institut du Droit & 1,710 & 1,121 & 443 & 16 & 130 & & 50 \\
\hline e l'Agriculture & 1,320 & 860 & 460 & & & & \\
\hline Bureau des Manuels Scolaires & 5,250 & 1,100 & 1,200 & 2,900 & 50 & & 300 \\
\hline ublic library & 251 & 65 & 43 & 40 & 91 & 12 & 162 \\
\hline Luang Prabang public library & 5,048 & & 385 & 4,603 & 60 & & 100 \\
\hline Lao library subtotals & 36,514 & 17,016 & 7,545 & 8,954 & 1,145 & 1,854 & 1,384 \\
\hline \multicolumn{8}{|l|}{ Foreign Libraries: } \\
\hline USIS library, Vien & 4,297 & 1,081 & 2,785 & 145 & 16 & 270 & 610 \\
\hline USIS library, Luang Prabang & 2,748 & 1,191 & 1,174 & 163 & 26 & 194 & 105 \\
\hline USIS library, Savanakhet. & 2,528 & 737 & 32 & 164 & 33 & 412 & 179 \\
\hline USIS library, Pakse. & 2,686 & 991 & 1,225 & 188 & 56 & 226 & 133 \\
\hline American Sc & 3,100 & & 3,100 & $\ldots$. & & $\ldots$ & 2,250 \\
\hline British Information Service & 2,687 & & 2,687 & $\ldots$. & $\ldots$ & $\ldots$. & 168 \\
\hline Centre Cultural Français & 4,076 & 4,076 & & $\ldots$. & $\ldots$ & $\ldots$. & 512 \\
\hline United Nations staff library & 1,507 & 1,000 & 507 & & & $\ldots$ & \\
\hline \multirow{2}{*}{$\begin{array}{l}\text { USIAD technical library } \\
\text { Foreign language subtotals }\end{array}$} & 3,275 & & 3,210 & 11 & 54 & & 189 \\
\hline & 26,904 & 9,076 & 15,870 & 671 & 185 & 1,102 & 4,151 \\
\hline Totals & 63,418 & 26,092 & 23,415 & 9,625 & 1,330 & 2,956 & 5,535 \\
\hline
\end{tabular}


railroads or navigable rivers, and because of the current armed conflict between rival native factions. As a result, Laos in 1965 had a national income of $\$ 22$ million whereas Oregon earned more than $\$ 5.3$ billion. It is not surprising that Laos spent only $\$ 10,588$ last year for its national archives, museum, and literary committee, whereas Oregon spent $\$ 1,849,660$ for the Portland public library alone. The Lao National Archives has a cataloged collection of 840 books of which 55 are circulating annually, whereas the Portland public library has a collection of 896,917 volumes of which $3,504,963$ circulated in 1965 . The number of readers in Laos is much smaller than the number in Oregon, in part because of educational differences. There were only 7,279 Lao students in the sixth grade last year compared to Oregon's 37,061 , and only 290 Lao students in the twelfth grade compared with 31,127 in Oregon.

It is clear from these general statistics that rapid development of all kinds is needed in Laos. Yet the nation lacks resources, and among its greatest needs is some kind of library service. To see how Laos is helping itself in this respect, let us take a closer look at its libraries.

Laos has nineteen independent libraries and an undetermined number of bookshelves. Ten of the libraries are under Lao jurisdiction; the other nine are run by foreign missions. This paper will focus upon the ten Lao libraries.

Libraries in Laos are small; not a single collection exceeds ten thousand volumes in size. Three different libraries are called the "National Library," but in fact none of them does the job of a national library. The National Archives does not collect Lao materials and it loans its books out. The National Museum has a large collection of old Pali and Sanskrit books, but it treats them as items without monetary or intellectual value. Thao Kéne has written of the latter, "The building is well suited for a museum, but its plan has none of the desirable features of a library." The National Library, also called the Rockefeller library, circulates only French books and does not have any material about Laos.

Together, the nineteen libraries contain a total of 63,418 volumes. The ten Lao libraries house 58 per cent of these books, but only account for 25 per cent of the nation's total book circulation. The other 42 per cent of the books are circulated by the foreign libraries and account for 75 per cent of all circulation. Although the foreign libraries may have set many good examples, most Lao librarians have never visited them, nor indeed have they ever seen a library anywhere. The accompanying Table 1 summarizes data on all libraries in Laos.

At first it may seem strange that only 2.2 per cent of the books in Lao libraries are in the national language, but the Lao has never had a distinguished literary history, there being 134 Lao books in print. If Laos wishes to increase its library resources, it must turn to foreign languages, and the most logical second language is Thai. There is an abundance of Thai publishing, and Thai books have the same religious and cultural elements which are present in Laos; furthermore most people who are literate in Lao can read Thai also.

Lao libraries circulate few books. This presents a major problem because circulation is often the basis upon which a library attempts to justify its existence. To increase book circulation in the schools, library use must be integrated into the school curricula. This is being done at the American School in Vientiane, and its circulation is notably higher than those of other Lao libraries. To increase circulation in general, however, libraries need more books of quality. USIS has circulated almost as many English books as French books, yet many more people understand French because it is the language of instruction from the fourth grade on. Together, the American 
School and USIS circulated about 60 per cent of all books in Laos in 1966.

In addition to their unbalanced language holdings and their low circulation of books, libraries in Laos are plagued with a host of other problems. They are unorganized, poorly staffed, confused about their function, and lacking funds. Organization is chaotic and unstandardized. Four Lao libraries organize the books on their shelves according to Dewey, one according to its own subject classification, two by accession number, and three with no organization whatsoever. The two libraries with accession arrangements have subject card catalogs, but there are no double entries or cross references. None of the other libraries has a subject catalog, but all libraries in the country can boast of having the ubiquitous and useless accession lists. Card catalogs are about to come into use; the National Archives has purchased two hundred catalog drawers and is now ordering cards.

When Laos decides to organize its libraries, it will have a relatively simple task. The eighth edition of Dewey has already been translated into Thai, and the Ecole Supérieure de Pédagogie has translated the second summary of Dewey into Lao and French. The relative index to Dewey can be used instead of a subject card catalog, since libraries need subject indexing but do not have the staff to use Sears, which is not available in Thai. There needs to be a program to teach the use of Dewey both to the staff and to library patrons. Some basic materials have been developed in Lao, but more are needed. On the use of Dewey, the Americans, French, and British are in agreement since all of their information services now use it. Nothing will really be accomplished, however, until the Lao themselves adopt this system. The Lao will also wish someday to form a library association; this could help standardize the use of Dewey, produce needed materials and guides, and give advice to libraries and help train librarians.

Staffing of libraries is a real problem. Most libraries are run by one person whose main function is to circulate and shelve books. No one has been trained to administer, to do technical services, or to provide reference service in a library. Present library staff time is frequently being wasted upon clerical and secretarial tasks which have nothing to do with the library at all, but which are imposed by their parent organizations.

Lao libraries are often confused about their functions. In schools, the function of a library is usually seen as a textbook dispensary and a study hall; it has not yet come to be viewed as a rich variety of supplementary material which is of potential use in the curriculum. In the National Archives, the function is being confused with that of a public library and a museum; there is no library in Laos which has the archival function of collecting all books in the Lao language and about the nation of Laos, and preserving them by never loaning them out. Lao libraries are still young, but the longer the RLG waits to give them direction, the more firmly entrenched in poor library habits they will be, and the more costly they will be to change.

Libraries, however, do cost money to establish, to maintain, and to develop. Few Lao libraries have budgets, and even more rarely is the budget in the hands of the librarian. The UNESCO surveyor mentioned above prepared in detail a program of library development for Laos which, if approved, would cost the Royal Lao Government a total of $\$ 560,000$ over the next ten years. It is for the RLG alone to decide whether it can support and profit from library development in Laos.

At the present time, there are several foreign library projects in Laos. U.S. AID, Education Division, has sent an IVS advisor to improve the libraries at the Ecole Supérieure de Pédagogie and 
at other teacher training schools. U.S.AID, Rural Development Division, has begun a program of supplying a shelf of books in Lao to the clusters- "clusters" are administrative groupings of villages. An IVS Rural Development volunteer has also started a small public library in Vang Vieng. Both USIS and the Asia Foundation have given some books to libraries requesting them. Such foreign efforts are fine in themselves, but as a stimulus to Lao library development they are of little value because the RLG has not yet supported them. Libraries in Laos are not always a good thing, but they could, as in more fully developed nations, fulfill an important function if they were given professional guidance and governmental support.

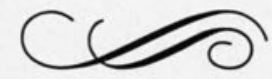

